\title{
MANAQIBAN OF SHAIKH ABDUL QADIR AL-JAILANI TRADITION: Study of Living Hadith in Kunir Wonodadi Blitar East of Java
}

\author{
Salamah Noorhidayati \\ IAIN Tulung Agung \\ salamahnoorhidayati@gmail.com
}

\section{Kharis Mahmud}

IAIN Tulung Agung

kharismahmud18@gmail.com

\begin{abstract}
This article examines the meaning of tradition in Syaikh Abdul Qadir Jailani's Manaqiban recitation in Kunir village, Wonodadi, Blitar. This article is written based on the research using qualitative method and phenomenology approach. Data collected from observation, interviews, and document reviews are analysed using Karl Manheim's theory of knowledge. This article demonstrates that, first, manaqiban tradition understood by the Kunir villagers as form of Islamic teaching guided by the Qur'an and the hadith and a medium for acquiring blessing from the Saint. Second, for the Kunir villagers, the manaqiban tradition has three meanings, i.e. objective meaning referring to a form of religious observance; expressive meaning referring to the motives jama'ah has in manaqiban participation; documentary meaning referring to the meaning of manaqiban as a means to preserve Islamic teaching and accommodate local culture in order to create religious and social life of society.
\end{abstract}

\section{Abstrak}

Artikel ini menelaah makna tradisi dalam pembacaan Manaqiban Syaikh Abdul Qadir Jailani di desa Kunir, Wonodadi, Blitar. Artikel ini ditulis 
menggunakan metode kualitatif dan pendekatan fenomenologi. Data dikumpulkan melalui observasi, wawancara, dan dokumen serta dianalisis dengan teori pengetahuan Karl Manheim. Artikel ini menunjukkan bahwa, pertama, tradisi manaqiban yang dipahami oleh penduduk desa Kunir merupakan bentuk ajaran Islam yang dipandu oleh al-Qur'an dan hadis dan sebagai media untuk memperoleh berkah dari Orang Suci. Kedua, untuk penduduk desa Kunir, tradisi manaqiban memiliki tiga makna, yaitu makna objektif yang mengacu pada suatu bentuk ketaatan beragama; makna ekspresif mengacu pada motif jama'ah dalam partisipasi manaqiban; dan arti dokumenter mengacu pada makna manaqiban sebagai sarana untuk melestarikan ajaran Islam dan mengakomodasi budaya lokal untuk menciptakan kehidupan sosial dan keagamaan masyarakat.

Keywords: Karl Manheim, Manaqib, Meaning, Sociology of knowledge.

\section{A. Introduction}

Manaqiban is not a foreign term for Indonesian people. Manaqiban is one of the traditions practiced in many regions in Indonesia. ${ }^{1}$ There is a difference of perception among scholars and Muslims related to the implementation of manaqiban, both in terms of law and ritual. Some see that manaqiban is a form of implementation of Islamic teachings, but others see that it a practice that has no legal basis for its implementation and is considered to deviate from Islam. The differences are also found in the practice of ritual procession. It focuses on the ritual "istighatsah" that is reading the prayers at the end of the manaqib book and some are just "dulkadiran" the meal-eating ceremony with a variety of dishes. Apart from these differences, in reality, this tradition exists and lives in parts of Indonesia. ${ }^{2}$

Manaqiban is a tradition of reading the narration of the "life story" of a character or person who is regarded as a Saint, which contains the goodness of charity and his soul. Therefore, thesewords are dedicated to the

${ }^{1}$ Ta'rifin, Ahmad. "Tafsir Budaya atas Tradisi Barzanji dan Manakib.” Jurnal Penelitian 7, no. 2 (24 Oktober 2012). https://doi.org/10.28918/jupe.v7i2.107.

${ }^{2}$ Widiyanto, Asfa. "Manaqib Writing in the Circle of the Tariqa Qadiriyya Wa Naqsyabandiyyah: A Study on Muhammad Siddiq al-Salihi's Nayl al-Amani.” Heritage of Nusantara: International Journal of Religious Literature and Heritage 4, no. 2 (18 Januari 2016): h. 213-42. 
noble ones, such as Umar ibn al-Khattab, where al-ibn ibn Abi Talib, Junaydi al-Baghdadi, Sheikh Abdul Qadir al-Jailani, and so on. ${ }^{3}$

The traditions of manaqiban that are carried out in some parts of Indonesia show the pattern of reception of the Muslim community to the teachings of the Qur'an and hadith. This tradition goes hand in hand with other traditions such as yasinan, tahlilan, istighatsahan, and shalawatan. In the majority, manaqiban which implemented is manaqiban of Shaikh 'Abd al-Qadir al-Jailani, although there are also other manaqib, especially in Java. ${ }^{4}$

People in Java are so intimately connected with this activity because it is considered to be a positive value. In addition to spiritual value, this activity is also a social value to establish friendship between family members and neighbors. Even in the life of the tarekat, manaqiban is a ritual activity that is no less sacred than other rituals. In addition to the routine activities carried out each month, this activity can also be incidental at the request of the community according to theirevents.

Kunir Village is an agrarian area in the District of Wonodadi of Blitar Regency with the majority of the population are a farmer and the community uphold the value of religions. ${ }^{5}$ In this area, there is also some Islamic Boarding School which colored the religious of the surrounding community, namely Al-Kamal Integrated Boarding School, ${ }^{6}$ Mahayatul Qurro Islamic Boarding School ${ }^{7}$ and the cottages outside Kunir village are almost near. In

${ }^{3}$ Moh. Saifulloh al-Aziz, Terjemah Manaqib (Kisah Kehidupan) Syaikh Abdul Qadir Jailani, (Surabaya: Terbit Terang, tt), h. 11.

${ }^{4}$ Ta'rifin, Ahmad. "Tafsir Budaya atas Tradisi Barzanji dan Manakib."

${ }^{5}$ Kharis Mahmud, "“Nilai-nilai Sunah Nabi dalam Tradisi Manaqib Syaikh 'Abdul Qadir al-Jailani”, Skripsi, (Tulungagung: IAIN Tulungagung, 2017), h. 6.

${ }^{6} \mathrm{Al}-$ Kamal Integrated Boarding School was founded in 1940 by KH. Manshur, one son of KH. Imam Basyari (he is one Kiai in Pondok Pesantren al-Fatah Mangunsari Tulungagung), it was continued by his sons in law, KH. Thohir Wijaya and KH. Thobib. Based on istikharah results of KH. Thohir Wijaya, this Islamic Boarding School which originally named Kunir Islamic Boarding School changed into Al-Kamal Integrated Boarding School. This change has implications for paradigm change and system. It was originally pure salafiyah (klasik) system and finally combined with ashriyah (modern) with integrated learning system betweensoroganandbandonganwith classical system. With classical system, the changes bring possitive impact on the development and dynamics of education in this boarding school.

${ }^{7}$ Mahaytul Qurro' islamic Boarding school was founded by KH. Ahyat approximately 50 years ago, it was one of Islamic boarding school which concentrates on Qur'anic learning and memorizing. Geographically, it is near with Al-Kamal boarding school, around 500 meters. 
the midst of a condition of society with a high degree of religiosity, there are several religious traditions that run from time to time and manaqiban is one of them.

An interesting thing in this village tradition is that its membership consists of people of all ages, some are still students, collage students, family member, and the elderly. Although busy in searching for wealth for their families, they still took the time to enliven the activities of manaqiban. Their motivation to follow is not only for the sake of the world but also more oriented towards the hereafter. ${ }^{8}$ Their motivation is based on some hadiths ${ }^{9}$ which contained in the book of reference for the practice of this manaqiban. Like the books of Nurul Burhani fi Tarjamah al-Lujaini ad-Dani ${ }^{10}$ and Bughyat Al-Mustarsyidin, ${ }^{11}$ These traditions are often used as the basis of the urgency of loving and imitating the doctrine of Allah's saints, especially to mention Sheikh Abdul Qadir al-Jailani who is regarded as Qutb al-'auliya (the leader of saints). One proof of the love of the saints is to read and remember the biography and character which formulated in the story in manaqib book.

This paper focuses on the existing tradition of Kunir village Wonodadi Blitar, by making followers member of the traditions of manaqiban as the subject of research. Based on the observation, the followers of jama'ah manaqiban showed great enthusiasm in addition to the variation of members, both in terms of age and occupation. The young men eagerly spend some of the night participating in the event. Likewise, the elder members continue to present in this activity with great enthusiasm.

This phenomenon becomes interesting to investigate. In addition, to increased insight into the various forms of religious community, this study aims to reveal one form of community receptions to a particular hadith and represent a phenomenon that occurs in Kunir village related to living hadith.

Based on the background above, the focus of this research is to reveal the meaning of tradition of manaqiban in Kunir village. There are two problems: 1) How is the understanding of Kunir Wonodadi Blitar

${ }^{8}$ Mahmud, "Nilai-nilai Sunah ...", h. 11.

${ }^{9}$ The example of hadiths are read Muhammad bin Ismail al-Mughirah al-Bukhori, Shahih Bukhori Juz VIII, (Kairo: Dar Asy-Sya'ab, 1987), h. 131. No 6502

${ }^{10} \mathrm{Abu}$ Luthfi Hakim dan Hanif Muslih bin Abdur Rohman, Nurrul Burhani fi Tarjamah al-Lujaini ad-Dani, (Semarang: Toha Putra, 1422), h. 1.

${ }^{11}$ Abdurrohman bin Muhammad bin Husain bin Umar Ba'lawi, Bughyat alMustarsyidin, (tt: Dar al-Fikr, tt). 
community about manaqiban? 2) and what is the meaning of manaqiban for the people of Kunir Wonodadi Blitar? The purposes of this research are: 1) to reveal the understanding of the community of Kunir Village Wonodadi Blitar about manaqiban, and 2) To construct the meaning behind the tradition.

There were several studies which discussed the tradition of this manaqiban. Among these were done by $\mathrm{M}$. Awaludin. His research entitled "The Tradition of Manaqiban Sheikh Abdul Qadir Jailani at Pondok Pesantren Az-Zainiyah Sukabumi" focused on the development aspects of this group. ${ }^{12}$ While FA Hanif in his research on "The Influence of Tradition Reading Manaqib of Shaykh Abdul Qadir Jailani in Effort Improving Santriwati Spiritual Intelligence" focused on the effects arose from reading manaqib to the readers especially to Purwoasri Moslem students. This research is preceded by a description of the implementation of manaqib and the condition of spiritual santriwati. ${ }^{13}$

Rizem Aizid examined the "Signs in In Dzikir Manaqib Shaykh Abdul Qadir Jailani In Al Qadiri Jember Boarding School". This research focused on the symbolic aspect of the sign, namely the deciphering of the signs in Dzikir Manaqib. ${ }^{14}$ Research on the "Reception of the Quranic Verse on Manaqib Shaikh Abd al-Qadir al-Jailani in the Book of Al-Nur al-Burhani Tarjamati al-Lujjaini al-Dani "was performed by Arif Budianto. This research Focused on the discussion about the understanding of the people to the verses which they recited from manaqib book of Shaikh Abd al-Qadir al-Jailani. ${ }^{15}$

Kharis Mahmud's study about "The Sunna values of the Prophet in the Tradition of Manaqib Shaikh 'Abd al-Qadir al-Jailani in Kunir Village

${ }_{12}$ M. Awaludin, Tradisi Manaqiban Sheikh Abdul Qadir Jilani di Pondok Pesantren Az-Zainiyah Sukabumi, (digilib.uinsgd.ac.ad, 2014).

${ }^{13}$ Hanief, Farida Aisyah, Pengaruh Tradisi Membaca Manaqib Syaikh Abdul Qadir Jilani dalam Upaya Meningkatka Kecerdasan Spiritual Santriwati Pondok Pesantren Ahmada Hikmah Purwoasri Kediri, Thesis, (Surabaya: UIN Sunan Ampel Surabaya, 2017)

${ }^{14}$ Rizem Aizid, Tanda-Tanda Dalam Dalam Dzikir Mqanaqib Syaikh Abdul Qadir Jilani Di Pondok Pesantren Al Qadiri Jember, Skripsi Thesis, UIN Sunan Kalijaga, 2014.

${ }^{15}$ Arif Budianto, Resepsi Terhadap Ayat-Ayat al-Qur' an pada Manaqib Syaikh Abd al-Qadir al-Jailani dalam Kitab Al-Nur al-Burhani fi Tarjamati al-Lujjaini al-Dani, Skripsi Thesis, UIN Sunan Kalijaga Yogyakarta, 2016. 
(Living Hadith Study) precedes this research. ${ }^{16}$ In his thesis, he discussed the traditions of manaqib in various aspects, ranging from practical aspects, understanding and extracting sunnah values from the tradition of manaqib.

In addition to these works, it is also realized that there are still many studies that discuss manaqib of Sheikh Abdul Qadir Jailani. This article is a continuation of the author's joint research, so the equation of data can not be avoided. However, this article still has a different point from the previous thesis. This difference occurs in focus and research objectives which has implications for the different theories used and the results concluded. The focus of this research is to reveal the meaning ofthe tradition of manaqib in Kunir village, using the theory of the sociology of Karl Mannheim's knowledge. Of course, this difference is expected to contribute an added value to previous studies.

\section{B. Theoretical Review}

Looking at the tradition of manaqiban in Kunir village of Blitar, the Theory of Sociology of knowledge put forward by Karl Mannheim is suitable to apply. ${ }^{17}$ This theory is used to trace the behavior and meaning of the action of jama'ahmanaqiban in Kunir village of Blitar.Karl Mannheim argued that human action is formed from two dimensions of behavior and meaning. Therefore, to understand a social action, a scientist must examine the external behavior and the meaning of that behavior. Mannheim classifies and distinguishes the meaning of the behavior from a social action into three kinds, namely the objective meaning, expressive meaning, and documentary meaning. The objective meaning is the meaning determined by the social context which in it takes place; the expressive meaning is the meaning indicated by the actor and the documentary meaning is the hidden meaning, so the actor is not fully aware that an aspect that is expressed overall the culture.

There are two principles of Mannheim's theory of the sociology of knowledge. The first principle is there is no way of thinking (mode of though) that can be understood if its social origin has not been clarified. The ideas initiated by the people, the meaning and the source of the idea can not

${ }^{16}$ Kharis Mahmud, "Nilai-nilai Sunah Nabi dalam Tradisi Manaqib Syaikh 'Abdul Qadir al- Jilani di Desa Kunir (Kajian Living Hadis)”, Skripsi (Tulungagung: IAIN tulungagung, 2017)

${ }^{17}$ Karl Mannheim, Ideologi dan Utopia, Menyingkap Kaitan Pikiran dan Politik, terj. F. Budi Hardiman, (Yogyakarta: Kanisius, 1991), h. 287. 
be understood properly if their social foundations have not been determined yet. That means an idea must be understood in relation to the society that produces and applies it in its life. The second principle is ideas and ways of thinking, as well as the social entities, meanings and thinking styles associated with them will change and shift in line with the historical changes of an entity in question. ${ }^{18}$

This Mannheim theory is used as a basic reference in the background or historical discussion of the tradition of manaqiban, encompassing contextual origins and normative origins, namely the understanding of the characteristics of manaqiban and traditions about the virtues of the Saint. Furthermore, the author explains the behavior and meaning of the phenomenon of the traditions of manaqiban, including objective, expressive and documentary meaning.

\section{Research Method}

The type of this research is field research with the model of living hadith. ${ }^{19}$ In the study of living hadith, the researchers try to describe the object in the overall behavior that is done, ie from the history of the emergence of behavior, the behavior itself and the things that surround it, the relationship between the history of the emergence of behavior with behavior, as well as others matters relating to such behavior. One of the purposes of research with living hadith is to photograph the society's perception of the traditions that are implemented in the midst of Islamic society. ${ }^{20}$

\footnotetext{
${ }^{18}$ Gregory Baum, Agama dalam bayang-bayang, h. 18.
}

${ }^{19}$ Living hadith study has four forms offered, namely: first, Text study (Textual Interpretation), second, study of reread of the texts (Texts Reinterpretation), third, Text Reconstruction, and fourth, study of muslim social phenomena related to the Qur'an and Hadiths. This research includes the fourth form which is about study of muslim social phenomena related to Hadiths. Nurun Najwah, Metodologi Penelitian Living Qur'an \& Hadits, Edit. Syahiron Syamsuddin, (Yogyakarta: Teras, 2007), h. 132 - 134. Mahmud, "Nilai-nilai Sunnah ...", h. 24.

${ }^{20}$ Qudsy, Saifuddin Zuhri. “Living Hadis: Genealogi, Teori, dan Aplikasi.” Jurnal Living Hadis 1, no. 1 (6 Desember 2016): h. 177-96. https://doi.org/10.14421/livinghadis.2016.1073; Suryadilaga, Muhammad Alfatih. “Komik Hadis Nasihat Perempuan: Pemahaman Informatif dan Performatif." Jurnal Living Hadis 2, no. 2 (15 Maret 2018). https://doi.org/10.14421/livinghadis.2017.1333. 
There are two sources of data, primary and secondary. This data is gained from observation, interview, and documentation. ${ }^{21}$ In this research, the primary data source is data source obtained and collected directly from informants, indigenous people of Kunir village in a various young to old as well as various professions respectively. While the secondary data source is the source of research data obtained indirectly through intermediate media including documentation of activities, books whichcontain the theme of this research. All these data are expected to provide a description of the implementation of the tradition of manaqiban..$^{22}$

The research subjects are a group of manaqiban consisting of administrators, members, and religious leaders. The subject here isas primary source or informant. To take the information, a purposive sampling technique is used, that is sampling technique or the selection of research subject or data source with a certain consideration, for example, that person is considered most know about what we need, or because of position and role in this area. ${ }^{23}$

The data analysis technique is descriptive-explanative one. The descriptive analysis is to analyze the data described by constructing typology. In the context of this research, the authors describe the results of interviews and classify the object of research on anyone who follows this tradition, how the background of each and when the implementation. The explanatory analysis is used to find reasons and specific motives following the tradition of manaqiban. The search for the meaning behind the tradition of manaqiban used the sociological theory of knowledge from Karl Mannheim.

This research used the phenomenology approach. ${ }^{24}$ The essence of phenomenology is to know deeply about socio-cultural phenomena which

${ }^{21}$ Nana Sudjana Ibrahim. Penelitian dan Penilaian Pendidikan, (Bandung: Sinar Baru,1984, h. 4

${ }^{22}$ Mahmud, "Nilai-nilai Sunnah...", h. 26.

${ }^{23}$ Sugiyono, Metode Penelitian Pendidikan, Pendekatan Kuantitatif, Kualitatif dan R\&D, (Bandung: Alfabeta, 2010), h. 300.

${ }^{24}$ Noeng Muhadjir, Metodologi Penelitian Kualitatif, (Yogyakarta: Rake Sarakan, 1991), h. 27. Pendekatan fenomenologi ini hampir sama dengan pendekatan etnografi. Etnografi adalah adalah pekerjaan mendeskripsikan kebudayaan yang bertujuan untuk memahami suatu pandangan hidup dari sudut pandang penduduk asli. Dalam bahasa Bronislaw Molinowski, tujuan etnografi adalah memahami sudut pandang penduduk asli dan hubungannya dengan kehidupan untuk mendapatkan pandangannya mengenai dunia 
are seen from the perception, thought, willingness and belief of the research subject (the community) about something outside of the subject. This approach is used to uncover the view of research subject including the traditions, rituals, ceremonies or practices they undertake. The researcher is "silent" and tasked with exploring the theoretical perspective of the research subject about tradition and joint into the habit of research subject which is examined (emic) ${ }^{25}$ Operationally, this approach is used to uncover the views and meanings of the traders of manaqiban.

\section{Data Analysis}

\section{Brief Explanation about Manaqib of Shaykh Abdul Qadir al- Jailani}

Manaqib in term is a story of pious men or women, like the story of the Prophet or the saint of Allah (beloved of Allah). In its tradition, the story is written in a very beautiful language with a beautiful sentence arrangement (balaghi). ${ }^{26}$ Whereas manaqiban is the activity of reading "manaqib" story of a certain character. In the Javanese region, the majority of the traditions of manaqiban are attributed to Shaykh 'Abd al-Qadir al-Jailani, ${ }^{27}$ although there are also other ones. The recitation of manaqib is to commemorate the struggle, scholarship, and various attitudes of Sahib al-Manaqib, and also intended to remember the achievement and the implementation of vows because the wishes are achieved. ${ }^{28}$

Sheikh 'Abd al-Qadir al-Jailani was born on $1^{\text {st }}$ Ramadan 471 Hijriah or 1077 BC in Naif Village including Jailan area located on the riverside of

(world view). James P. Spadley, Metode Etnografi, terj. Misbah Zulfa Elizabeth, (Yogyakarta: PT. Tiara Wacana, 1997), h. 3-5

${ }^{25}$ Suwardi Endraswara, Metodologi Penelitian Kebudayaan, (Yogyakarta: Gadjah Mada University Press, 2006), h. 44.

${ }^{26}$ Thohir, Ajid. "The Prominent Historiography as Strengthening the Schools of Fiqh and Sufism." Heritage of Nusantara: International Journal of Religious Literature and Heritage 1, no. 1 (25 Januari 2016): h. 121-54.

${ }^{27}$ Danusiri, Danusiri. "Growing up the Religious Potential from Religious Community of Qadiriyah wa Naqsyabandiyah Dawe Kudus.” Analisa: Journal of Social Science and Religion 19, no. 1 (7 Juni 2012): h. 27-36. https://doi.org/10.18784/analisa.v19i1.153.

${ }^{28}$ Widiyanto, Asfa. "Manaqib Writing in the Circle of the Tariqa Qadiriyya Wa Naqsyabandiyyah: A Study on Muhammad Siddiq Al-Salihi’s Nayl Al-Amani." 
Dajlah, which is one of the cities in the State of Tabaristan. ${ }^{29}$ The full name of Shaykh 'Abd al-Qadir al-Jailani is Abu Muhammad' Abd al-Qadir ibn Abi Salih 'Abd Allah ibn Janki Dauzat ibn Yahya ibn Muhammad ibn Dawud ibn Musa ibn' Abd Allah ibn al-Hasan bin 'Ali ibn Abi Talib. ${ }^{30}$ So, his nasabcame to the Prophet Muhammad, through the Fatimah bint Muhammad. ${ }^{31}$

Shaykh 'Abd al-Qadir al-Jailani continued to spreads his preaching and strived in the way of Allah, until he died on $10^{\text {th }}$ Rabi 'al-Akhir $561 \mathrm{H}$ at 90 years old more, and was buried in his madrasah "Bab al-Azaj" in the city of Baghdad. ${ }^{32}$ Shaykh 'Abd al-Qadir al-Jailani is a great' ulama 'among the ranks of people whose names are listed in the world of Islamic history. He is a mujahid who dislikes and rejects luxury life to live in God's guidance and obey the rules of Islam. From his attitude and good personality, arose stories in the form of neatly arranged writings, called "Kitab manaqib" with the intention to be made a lesson for Muslims who read and study it.

The book of Manaqib of Shaykh'Abd al-Qadir al-Jailani which spread widely in the midst of Islamic society in Indonesia today, is written by a theologian of Indonesia derived from venerated books like Lujayn alDani, Tafrih al- Khatir, and so forth. the book of Manaqib Shaykh 'Abd alQadir al-jailani which spread widely in Indonesia today is usually printed using Arabic writing and form, at its lower part is translated in Javanese Arabic pegon, as can be seen in book Manaqib al-Nur al-Burhan "by A. Lathif Karim, the book" Miftah al-bab al-Amini "by Hambal Semarang, and the book" Lubab al-Ma'ani "by Mustamir Abu Shaleh of Juwana Pati.

\section{History of Manaqib}

Manaqib tradition has its institutional basis on the Qur'an and hadith. In the Qur'an, there is actually a doctrine to commemorate certain figures, such as the story of Ashabul Kahf or Manaqib Ashabul Kahf, king of

\footnotetext{
${ }^{29}$ Maulana Syamsyuri, Perjalanan Hidup Syaikh Abdul Qadir al-Jailani, (Surabaya: Gresinda Press, tt), hal. 6. Lihat juga Al-Barzanji, Al-Lujain Al-Dani, terjemah Muslih Abdurrohman, Al-Burhani, jilid II (Semarang: Toha Putra, tt), h. 14.

${ }^{30} \mathrm{Al}-\mathrm{Barzanji}$, Al-Lujain Al-Dani, terjemah Muslih Abdurrohman, Al-Burhani, jilid II (Semarang: Toha Putra, tt), h. 15.

${ }^{31}$ Habib Abdullah Zaki al-Kaaf, Ajaran Tasawuf Sheikh Abdul Qadir al-Jailani, (Bandung: Pustaka Setia, 2003), h. 11; Thohir, Ajid. "The Prominent Historiography as Strengthening the Schools of Fiqh and Sufism." Heritage of Nusantara: International Journal of Religious Literature and Heritage 1, no. 1 (25 Januari 2016): h. 121-54.

${ }^{32}$ Moh Saifullah Al-Aziz, Terjemahan Manaqib, (Surabaya: Terbit Terang, 2000), hal. 8 .
} 
Dzul Qarnain, manaqib Lukman, manaqib Maryam bint 'Imran and so on. ${ }^{33}$ Likewise, after the Messenger of Allah (SAW) died, there were many others manaqib, such as Abu Bakr, 'Umar, 'Usman, 'Ali binAbi Tholib, manaqib Hamzah, manaqib Abi Sa'id, manaqib Junaidi Al-Baghdadi, manaqib AtTijani,and manaqib Shaykh Abdul Qadir al-Jailani. It's the last manaqib which is the most pleasing and famous in Indonesia ${ }^{34}$.

The history about the development of manaqiban in Indonesia began since the coming of Islam in Indonesia, especially on the Java island, initiated by preachers and saints led by WaliSongo. They teach the Islamic community about tasawuf and their experiences, among them, manaqib and other deeds. The tradition of manaqib still exist until now and continue to develop in Islamic society, even used as a means of Islamic da'wah. ${ }^{35}$

The tradition of reciting manaqib Shaykh Abdul Qadir al-Jailani according to some Muslim societies has an important value in improving beliefs and worship. Therefore, this tradition is hereditary and continues to be preserved and become one of the traditions of Islamic culture that are often performed in various events ${ }^{36}$.

Historically, in Kunir village, a group of manaqiban of Sheikh Abdul Qadir al-Jailani was initiated by Mr. Hasyim approximately 30 years ago. Hasyim's father is a religious figure that lived in Kunir Village society. When he was young, he often followed manaqiban in Surabaya, exactly at Pondok Al-Fitroh Kuningan which held every week. Even this activity became an annual tradition commemorated as a "haul" ceremony attended by no less than ten thousand people. Based on personal experience in this religious social environment, Mr. Hashim established an organization of recitation of manaqib Sheikh Abdul Qadir al-Jailani. The struggle to introduce and preserve this tradition can be said not easy. At first, this group only followed by $8-10$ people only. But now the members reach50 - 60 people who are

${ }^{33} J u l i a n$ Milie, Greg Barton, Linda Hindasah, Mikihiro Moriyama. "Postauthoritarian diversity in Indonesia's State-Owned Mosques: A Manakiban Case Studi." Journal of Southeast Asian Studies 45, no. 2, Juni 2014: h. 194-213. https://doi.org/10.1017/S002246341400006X.

${ }^{34}$ Agus Riyadi. "Tarekat sebagai Organisasi Tasawuf (Melacak Tarekat dalam Perkembangan Dakwah Islamiyyah).” At-Taqaddum 6, no. 2, November 2014: 359-385. https://dx.doi.org/10.21580/at.v6i2.716

${ }^{35}$ Bani Sudardi, dan Afiliasi Ilafi. "Hegemoni Budaya dalam Tradisi Manaqiban." Madaniyah 7, no. 1, Januari 2017: h. 188-203

${ }^{36}$ Ta’rifin, Ahmad. "Tafsir Budaya atas Tradisi Barzanji dan Manakib." 
continuously attending activities every month. Until now, this activity is held every $11^{\text {th }}$ Hijriyah month or odd date after Isya' prayer. $^{37}$

\section{Hadiths about Manaqib}

The data discovered that the appearance of the tradition of manaqiban is based on some traditions that indicate to love, remember and imitate the theologians and auliyasalihin. Some of the hadiths are:

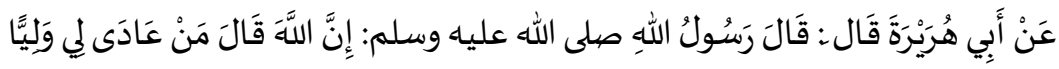

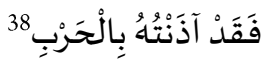

Meaning: "From Abu Hurairah said Rasulullah said Verily Allah says Whoever hurt my saints then he has declared war with me"

Another Hadith which is also the basis of holding Manaqiban are:

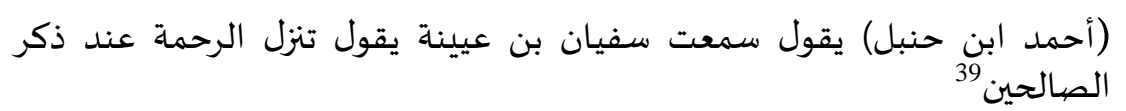

Meaning: (Sufyan bin Uyainah) ${ }^{40}$ said: "The decline of grace when someonespoke or mentioned Salih people"

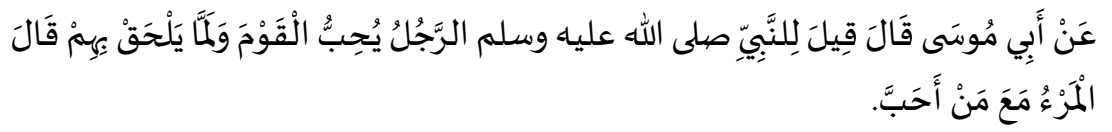

Meaning: "From Abu Musa that the Prophet SAW said:"the person will be with the person he loves"

${ }^{37}$ The result from the interviews with some official members of manaqib. Read, Mahmud, "Nilai-nilai Sunah...", h. 76-77.

${ }^{38}$ al-Bukhari, Shahih Bukhori Juz VIII, (Kairo: Dar Asy-Sya'ab, 1987), h. 131. No 6502.

${ }^{39} \mathrm{Abu}$ al-Fadl al-Muqri', Ahadits fi Damil Kalam wa Ahlihi, (Riyadz, Dar Atlas, 1996), h. 174.

${ }^{40}$ According to Ibnu Hajar al-Asqalani by quoting opinions Al-Iraqi said that actually it is not prophetic hadith but it is Sufyan bin 'Unayah statement. See Abu Ubaidah Yusuf bin Mukhtar as-Sidawi, Koreksi Hadis-Hadis Dha'if Populer, (Bogor: Media Tarbiyah, 2015), h. 181. 
The hadiths mentioned contain both demands and guidance to make a relationship with salihin people and to love them. Love and compassion are the basis of friendship. A person's love will bring him to his curiosity. Manaqiban is a medium to cultivate and build love and togetherness with loved ones, the saints of Allah.

\section{E. The Meaning of Manaqiban for the Community of Kunir Village Wonodadi Blitar}

The phenomenon of manaqiban in Kunir village followed by a group of various ages and professions exist in the midst of moderncontemporary social and religious traditions can be explained through the theory of sociologyof knowledge by Karl Mannheim as follows:

\section{The objective meaning}

The philosophical foundation of this activity was initiated by Mr. Hasyim who has the desire to revive religious activities in Kunir Village. According to him, the activities of manaqiban should be preserved and saved, because many verses tell the previous figures in the Qur'an, whetherit is fiction or nonfiction to take "ibrah" or lessons from his story.

Among these verses are Q.S Hud: 120

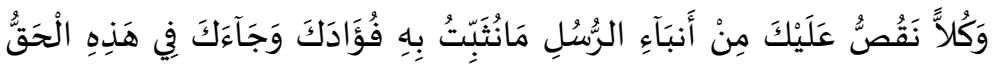

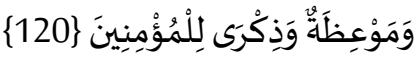

Meaning: "And all the stories of the Apostles We tell you, are the stories which We firmly establish your hearts; and in this letter has come the truth unto you and the instruction and the remembrance for those who believe.".

Similarly, the Prophet's hadith about the revelation of mercy for those who read or speak of the goodness of the salihin people mentioned:

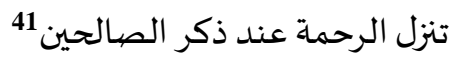

Based on the two sources of religion above it can be stated that the tradition of manaqiban, at least for the beginning, is a form of religious

${ }^{41} \mathrm{Abu}$ al-Fadl al-Muqri', Ahadits fi Damil Kalam wa Ahlihi, (Riyadz, Dar Atlas, 1996), h. 174. 
obedience that is an experience to the one of teaching Islam that teaches to love the saints of Allah SWT - in this case, the figure is Sheikh Abdul Qadir al-Jailani - and take exemplary of his attitudes and good morals. ${ }^{42}$

\section{Expressive Meaning}

According to Mr. Fauzi, the leader of manaqiban after Mr. Hashim, manaqib Sheikh Abdul Qadir Jailani is a story of a saint of God which consists of biography, karamah-karamah, knowledge, morals, and others. ${ }^{43}$ According to him, there are some motives to follow the activities of Sheikh Abdul Qadir al-Jailani. Among these is to plead Allah's ridla and expect blessings from Allah's saint, namely Sheikh Abdul Qadir Jailani. He felt the benefits of the activities of manaqiban namely inner peace, fulfillment of their need and the blessing of his sustenance. ${ }^{44}$

In addition, according to Mr. Fauzi, now it is required the existence of an activity that can rebuild good moral or al-akhlaq al-karimah as exemplified by the saints earlier. Manaqiban of Sheikh Abdul Qadir alJailani, in his view, can be used as a medium to instill the characteristics of the saint in order to fortify Muslims, especially for young generation from moral decadence. Reading and remembering the story and example of Shaykh Abdul Qadir al-Jailani through his manaqib is one way to remind and inculcate the morality of youth needed the guidance from parents. ${ }^{45}$

In another hand, Fauzi's participation in this group is also due to his desire to be a role model for family and society. He said: "It takes a male figure in a family who can guide and become a family model. If he does not study religion, how can he create a harmonious and loving family? $?^{46}$ According to him, through a group of manaqib, he can recognize the biography of Shaykh Abdul Qadir al-Jailani and his attitudes to take ibrah in guiding the family."

The same thing is also conveyed by Mr. Khoirul Hadi or commonly called as Mas Hadi, who is a member of the manaqiban group representing as young people. He has a motive that is similar to Mr. Fauzi, "If I act in an Islamic way, I will make a role model for my family and my environment.

\footnotetext{
${ }^{42}$ Fauzi, interview, Blitar: 12 Mei 2017. See Mahmud, "Nilai-nilai Sunah ...", h. 77

${ }^{43}$ Fauzi, interview, Blitar: 12 Mei 2017.See Mahmud, "Nilai-nilai Sunah ...”, h. 77

${ }^{44}$ Fauzi, interview, Blitar: 12 Mei 2017.See Mahmud, "Nilai-nilai Sunah ...”, h. 78

${ }^{45}$ Fauzi, interview, Blitar: 12 Mei 2017. See Mahmud, "Nilai-nilai Sunah ...", h. 78

${ }^{46}$ Fauzi, Interview, Blitar: 12 Mei 2017. Lihat Mahmud, "Nilai-nilai Sunah ...”, h.
}

84. 
Among the ways to be able to act in an Islamic way is to follow the manaqiban routinely. The reading of an exemplary story of role models can generate self-motivation to shape the personality based on that person. ${ }^{47}$

In addition to the motives above, the participation of mas Hadi in the manaqiban group is to get mercy. He quotes a hadith about the decline of the rahmah for those who mention the history of the pious people ${ }^{48}$ including among the righteous are Kyai Khalil Bangkalan, Kyai Hamid Pasuruan, and Gus Dur. ${ }^{49}$ According to his confession, during following manaqiban, he felt that he received many blessings in various things, including the sustenance gained. Although the sustenance earned in every day is not enough but always feel enough to fulfill his needs of life. In addition to the blessing of sustenance, he also gained much good in terms of worship and its mu'amalah. ${ }^{50}$

From the elder member of the group, Mr. Suyono said: "in this era, it is very rarethat an institution pays attention to the old. I am very happy with this agenda or manaqiban. Although the age is not young, he still gave the opportunity to participate dzikir routinely. ${ }^{~} 1$ According to Syamsudin, manaqiban is a majlis zhikr for the old man and by following it regularly he will get the peace of mind. There is a correlation between reading manaqiban and inner calm. The selection of the vocalist and the type of sound is adjusted to the parts of the reading manaqiban. This adjustment is intended for the listeners (jama'ah) that can really enjoy the sense of manakib when the vocalists recite manaqib well..$^{52}$ Moreover, when the procession manaqiban up to "mahal al-qiyam" or commonly called the "sirakalan" or "syrakalan", which sang the song "asyraqa 1 badru 'Alaina, at that time, all jama'ah stand, as a symbol of welcoming (tarhib) of the presence of the Prophet. For the jama'ah who can appreciate this procession, they imagine as if the Holy Prophet were present in this assembly. So that even is more felt solemn. ${ }^{53}$

\footnotetext{
${ }^{47}$ Khoirul Hadi, interview, Blitar: 14 Mei 2017. See Mahmud, "Nilai-nilai Sunah...", h. 85

${ }^{48}$ al-Muqri', Ahadits fi Damil Kalam, h. 174

${ }^{49}$ Khoirul Hadi, interview, Blitar: 14 Mei 2017. See Mahmud, "Nilai-nilai Sunah...", h. 86 .

${ }^{50}$ Khoirul Hadi, interview, Blitar: 14 Mei 2017. See Mahmud, "Nilai-nilai Sunah...", h. 86.

${ }^{51}$ Suyono, interview, Blitar: 15 Mei 2017.

${ }^{52}$ See Mahmud, "Nilai-nilai Sunah ...", h. 69.

${ }^{53}$ See Mahmud, “Nilai-nilai Sunah ...”, h. 70.
} 
Manaqiban can be made as a media of self-preservation to engage in various religious social activities in the community. Many community leaders who became members of this group became a prayer priest (imam), tahlil priests and prayers in various events. At least there is some recognition from members of the group, like Mr. Kasib, as follows: "Often I was in the neighborhood I was told to be a priest of tahlil or other celebration. I did not know why they chose me. They said that they often hear and like when I recite manaqib and make a complete tawasul and often follow this gathering once a month". 54

There are among members of the group who have a unique motive like Mr. Kasib. According to him, his participation in manaqiban is also to train and develop his voice talent in qira'at, as it is conveyed: "I followed this manaqiban in order to add my knowledge and to develop my voice which often asked to perform qiroat at various events such as marriage, aqiqahan,and others "55

From these confessions, it can be expressed some expressive meaning of manaqiban for Kunir society, these are: 1) asking ridla, grace and blessing from Allah. 2) Expect the blessings of Sheikh 'Abd al-Qadir al-Jailani as the saint of God. 3) Rebuild attitudes and morals of society. 4) As the majlis of dhikr in filling the old days. 5) Being a role model for families and communities. 6) Media of self-preservation to engage in various social religious activities in society. 7). Sharpen and train certain skills, that is qira'at art.

\section{The meaning of documentary: Establishing Synergy between Culture and Religion}

Based on the data above, it can be stated that the tradition of manaqiban is a religious social phenomenon which traced elements of normativity and historicity based on sacred texts. Manaqiban is one tradition that hereditary serve as a media to teach the values of kindness and exemplary. Unconsciously, the practice is undertaken by the villagers of Kunir village as an implementation of both textual and contextual understanding of the Qur'an and hadith, especially the hadith about privilege.

A saint of Allah. Ultimately, this tradition, along with other traditions, became an alternative media in preaching to teach Islamic values.

\footnotetext{
${ }^{54}$ Kasib, interview, Blitar: 13 Mei 2017. See Mahmud, "Nilai-nilai Sunah ...", h. 82.

${ }^{55}$ Kasib, interview, Blitar: 13 Mei 2017. See Mahmud, "Nilai-nilai Sunah ...", h. 86.
} 
Although it may be beyond understanding, it can not be denied that the existence of tradition (manaqiban) indicates religiosity and still firmly rooted in the Kunir village community.

As it is known that Islam consists of the main teachings in the form of aqidah, shariah, and muamalah. ${ }^{56}$ Based on observation and recognition (interview), in this manaqib tradition, it reflects three teachings which consist of religious, social, ethical and even intellectual..$^{57}$ The utilization of the manaqiban activity as the dhikr majlis, perform mau'idhah Hasanah and the planting of honorable values to religious figures, such as the Prophet, the Saints, and Salaf as- Salih indicate the existence of religiosity and intellectual elements. Whereas the activity of manaqiban is able to realize solidarity and solidity among members as well as with citizens. It is known from the members of the manaqiban group in Kunir village has a variation membership, both in terms of age, educational background and profession. ${ }^{58}$ That is the tradition of manaqiban contains ethical and social elements.

Thus, can be stated that the tradition of manaqiban contains the meaning of documentary that shows the existence of manaqiban as a synergistic form between the practice of Islamic teachings as well as the preservation of local traditions in order to create a religious social life of society in an atmosphere of unity, community and harmonious.

\section{F. CONCLUSION}

The study of living hadiths on the traditions of manaqiban concludes: 1) The tradition of manaqiban is understood as one form of Islamic teachings that are guided from the Qur'an and hadith and the media to seek blessings from the Salih. 2) There are three meanings in the tradition of manaqiban: First, objective meaning, as a form of religious obedience namely the experience of one religious teaching of Islam that teaches to love Allah's saint- in this case, is the figure of Sheikh Abdul Qadir al-Jailani - and takes the example of good attitudes and good deeds. Secondly, expressive meaning, which refers to some group motifs in following Manaqiban, among them: (1) pleading ridlo, grace, and blessing from God; (2). hoping for the blessing of Sheikh 'Abd al-Qadir al-Jailani as the saint of God; (3) rebuild attitudes and morals of society; (4) as the Majlis of dhikr in filling the old

\footnotetext{
${ }^{56}$ See Mahmud, “Nilai-nilai Sunah...”, h. 20-22.

${ }^{57}$ See Mahmud, "Nilai-nilai Sunah...”, h. 88

${ }^{58}$ See Mahmud, “Nilai-nilai Sunah ...”, h. 91.
} 
days; (5) being role models for families and communities; (6)as selfpreservation media to engage in various social activities in the community; (7) sharpen and train certain skills, namely qira'at art. Third, the meaning of documentary, which shows the existence of manaqiban as a media of practicing religious teachings once the preservation of local culture in order to create a religious social life of society in an atmosphere of unity, community and harmonious. [] 


\section{DAFTAR PUSTAKA}

Aisyah Hanief, Farida, "Pengaruh Tradisi Membaca Manaqib Syaikh Abdul Qadir al-Jailani dalam Upaya Meningkatka Kecerdasan Spiritual Santriwati Pondok Pesantren Ahmada Hikmah Purwoasri Kediri”. Thesis, UIN Sunan Ampel Surabaya, 2017.

Aizid, Rizem, "Tanda-Tanda Dalam Dalam Dzikir Mqanaqib Syaikh Abdul Qadir Jailani Di Pondok Pesantren Al-Qadiri Jember”, Skripsi, Yogyakarta: UIN Sunan Kalijaga, 2014.

An'im, Abu, Referensi Penting Amaliyah NU dan Problematika Masyarakat. Jawa Barat: Mu'jizat, 2010.

Awaludin, M., “Tradisi Manaqiban Sheikh Abdul Qadir Jailani di Pondok Pesantren Az-Zainiyah Sukabumi”, (digilib.uinsgd.ac.ad, 2014).

Aziz, Moh Saifullah Al-, Terjemahan Manaqib. Surabaya: Terbit Terang, 2000.

Aziz, Moh. Saifulloh al-, Terjemah Manaqib (Kisah Kehidupan) Syaikh Abdul Qadir Jailani. Surabaya: Terbit Terang, tt.

Ba'lawi, Abdurrohman bin Muhammad bin Husain bin Umar, Bughyat alMustarsyidin, .tt: Dar al-Fikr, tt.

Bani Sudardi, dan Afiliasi Ilafi. "Hegemoni Budaya dalam Tradisi Manaqiban.” Madaniyah 7, no. 1, Januari 2017: 188-203

Barzanji, Al-, Al-Lujain Al-Dani, terj Muslih Abdurrohman, Al-Burhani, jilid II, Semarang: Toha Putra, tt.

Baum, Gregory, Agama dalam Bayang-bayang Relativisme: Agama, Kebenaran dan Sosiologi Pengetahuan, terj. Achmad MurtajibChaeri dan Masyhuri Arow. Yogyakarta: PT Tiara Wacana, 1999.

Budianto, Arif, "Resepsi Terhadap Ayat-Ayat al-Qur'an pada Manaqib Syaikh Abd al-Qadir al-Jailani dalam Kitab Al-Nur al-Burhani fi Tarjamati al-Lujjaini al-Dani," Skripsi Thesis, UIN Sunan Kalijaga Yogyakarta, 2016.

Bukhari, Muhammad bin Ismail al-Mughirah al-, Shahih Bukhori Juz VIII, Kairo: Dar Asy-Sya’ab, 1987.

Danusiri, Danusiri. "Growing up the Religious Potential from Religious Community of Qadiriyah Wa Naqsyabandiyah Dawe Kudus.” 
Analisa: Journal of Social Science and Religion 19, no. 1 (7 Juni 2012): 27-36. https://doi.org/10.18784/analisa.v19i1.153.

Endraswara, Suwardi. Metodologi Penelitian Kebudayaan. Yogyakarta: Gadjah Mada Universy Press, 2006.

Hikmalisa, Hikmalisa. "Dominasi Habitus dalam Praktik Khitan Perempuan di Desa Kuntu Darussalam Kabupaten Kampar Riau (aplikasi Praktik Sosial Pierre Boudieu Dalam Living Hadis).” Jurnal Living Hadis 1, no. 2 (1 Oktober 2016): h. 324-73. https://doi.org/10.14421/livinghadis.2016.1124.

https://dx.doi.org/10.21580/at.v6i2.716

Ibrahim, Nana Sudjana. Penelitian dan Penilaian Pendidikan. Bandung: Sinar Baru, 1984.

Julian Milie, Greg Barton, Linda Hindasah, dan Mikihiro Moriyama. "Postauthoritarian diversity in Indonesia's State-Owned Mosques: A Manakiban Case Studi." Journal of Southeast Asian Studies 45, no. 2, Juni 2014: 194-213. https://doi.org/10.1017/S0022463414 00006X

Kaaf, Habib Abdullah Zaki al- Ajaran TasawufSheikh Abdul Qadir al-Jailani. Bandung: Pustaka Setia, 2003.

Mahmud, Kharis. "Nilai-nilai Sunah Nabi dalam Tradisi Manaqib Syaikh 'Abdul Qadir al-Jailani”, Skripsi, Tulungagung: IAIN Tulungagung, 2017.

Mannheim, Karl. "On The Interpretation of Weltanchauung, "Essays on The Sociology of Knowledge, London: Routhledge \& Kegan Paul, 1952

, Ideologi dan Utopia, Menyingkap Kaitan Pikiran dan Politik, terj. F. Budi Hardiman, Yogyakarta: Kanisius, 1991.

Muhadjir, Noeng. Metodologi Penelitian Kualitatif. Yogyakarta. Rake Sarakan, 1991.

Muqri', Abu al-Fadl al-, Ahadits fi Damil Kalam wa Ahlihi. Riyadz, Dar Atlas, 1996.

Muttaqin, Ahmad. “Barzanji Bugis' dalam Peringatan Maulid: Studi Living Hadis di Masyarakat Bugis, Soppeng, Sul-Sel.” Jurnal Living Hadis 1 , no. 1 (6 Desember 2016): h. 129-50. https://doi.org/10.14421/livinghadis.2016.1071. 
Najwah, Nurun, Metodologi Penelitian Living Qur'an \& Hadits, (Ed). Syahiron Syamsuddin. Yogyakarta: Teras, 2007.

Qudsy, Saifuddin Zuhri. "Living Hadis: Genealogi, Teori, dan Aplikasi." Jurnal Living Hadis 1, no. 1 (6 Desember 2016): 177-96. https://doi.org/10.14421/livinghadis.2016.1073.

Ramadhan, Reza Bakhtiar. "Latihan Hadroh di Dusun Banyunganti Kidul (Studi Living Hadis: Teori Fungsional Thomas F. O'dea).” Jurnal Living Hadis 2, no. 1 (16 Februari 2018): 49-66.

Riyadi, Agus. "Tarekat sebagai Organisasi Tasawuf (Melacak Tarekat dalam Perkembangan Dakwah Islamiyyah)." At-Taqaddum 6, no. 2, November 2014: 359-385.

Rohman, Abu Luthfi Hakim dan Hanif Muslih bin Abd ar-, Nurul Burhani fi Tarjamah al-Lujaini ad-Dani, Semarang: Toha Putra, 1422.

Sidawi, Abu Ubaidah Yusuf bin Mukhtar as-, Koreksi Hadis-Hadis Dha'if Populer. Bogor: Media Tarbiyah, 2015.

Spadley, James P. Metode Etnografi, terj. Misbah Zulfa Elizabeth. Yogyakarta: PT. Tiara Wacana, 1997.

Sugiyono, Metode Penelitian Pendidikan, Pendekatan Kuantitatif, Kualitatif dan R\&D, Bandung: Alfabeta, 2010.

Suryadilaga, Muhammad Alfatih, "Komik Hadis Nasihat Perempuan: Pemahaman Informatif dan Performatif." Jurnal Living Hadis 2, no. 2 $(15$ Maret 2018).

https://doi.org/10.14421/livinghadis.2017.1333.

Syamsyuri, Maulana, Perjalanan Hidup Syaikh Abdul Qadir al-Jailani. Surabaya: Gresinda Press, tt.

Ta'rifin, Ahmad, "Tafsir Budaya atas Tradisi Barzanji dan Manakib.” Jurnal Penelitian 7, no. 2 (24 Oktober 2012). https://doi.org/10.28918/jupe.v7i2.107.

Thohir, Ajid. "The Prominent Historiography as Strengthening the Schools of Fiqh and Sufism." Heritage of Nusantara: International Journal of Religious Literature and Heritage 1, no. 1 (25 January 2016): 121-54.

Widiyanto, Asfa, "Manaqib Writing in the Circle of the Tariqa Qadiriyya Wa Naqsyabandiyyah: A Study on Muhammad Siddiq Al-Salihi's Nayl Al-Amani." Heritage of Nusantara: International Journal of 
Religious Literature and Heritage 4, no. 2 (18 January 2016): 21342.

Widyaningsih, Riri, dan Muhammad Abdul Hanif, "Tradisi Ziarah Makam Masyayikh Pondok Pesantren Al Hikmah 2 (Teori Sakralitas Agama Emile Durkheim)." Jurnal Living Hadis 2, no. 1 (11 Februari 2018): 1-17. https://doi.org/10.14421/livinghadis.2017.1326.

Observasi lapangan

Interview dengan Bapak Fauzi, pada tanggal 12 Mei 2017.

Interview dengan Bapak Kasib, pada tanggal 13 Mei 2017.

Interview dengan Bapak Kasib, pada tanggal 15 Mei 2017.

Interview dengan Bapak Khoirul Hadi, pada tanggal 14 Mei 2017.

Interview dengan Bapak Suyono, pada tanggal 13 Mei 2017.

Interview dengan Bapak Suyono, pada tanggal 15 Mei 2017.

Interview dengan Bapak Syamsudin, pada tanggal 12 Mei 2017. 